\title{
Fluorination-enabled interface of PtNi electrocatalysts for high- performance high-temperature proton exchange membrane fuel cells
}

\author{
Peng Long ${ }^{1 \dagger}$, Shiqian $\mathrm{Du}^{1 \dagger}$, Qie $\mathrm{Liu}^{1 \dagger}$, Li Tao ${ }^{1 *}$, Cong Peng ${ }^{2}$, Tehua Wang ${ }^{1}$, Kaizhi Gu ${ }^{1}$, Chao Xie ${ }^{1}$, \\ Yiqiong Zhang ${ }^{3}, \mathrm{Ru} \mathrm{Chen}^{1}$, Shanfu Lu ${ }^{4^{*}}$, Yi Cheng ${ }^{1^{*}}$, Wei Feng ${ }^{2^{*}}$ and Shuangyin Wang ${ }^{{ }^{*}}$
}

\begin{abstract}
High-temperature proton exchange membrane fuel cells (HT-PEMFCs) bring new opportunities for portable power generation due to their outstanding advantages such as high tolerance to fuel/air impurities and simplified heat/water management. However, carbon-supported nanostructured Ptbased catalysts running at temperatures over $150^{\circ} \mathrm{C}$ are challenged by the severe aggregation and carbon corrosion, thus leading to poor durability. Herein, we demonstrate that dendritic Pt-Ni nanoparticles supported on fluorinated carbon black (white carbon black) could significantly enhance the performance and durability of HT-PEMFCs as the cathode catalysts running at $160^{\circ} \mathrm{C}$ due to the strong interaction of the $\mathrm{F}$ and $\mathrm{Ni}$ atoms to form a $\mathrm{Ni}_{x} \mathrm{~F}_{y}$ interface on Pt-Ni nanoparticles. With the formation of a stable $\mathrm{Ni}_{x} \mathrm{~F}_{y}$ interface, this integrated HT-PEMFC reached peak power densities of $906 \mathrm{~mW} \mathrm{~cm} \mathrm{~cm}^{-2}$ and demonstrated excellent durability at $160^{\circ} \mathrm{C}$ under anhydrous $\mathrm{H}_{2} / \mathrm{O}_{2}$ conditions. This mitigation strategy was applied to $\mathrm{Pt}$-alloy/C electrocatalysts and resulted in the elimination of $\mathrm{Pt}$ dissolution in practical fuel cells.
\end{abstract}

Keywords: fuel cells, fluorinated carbon, interaction, activity, stability

\section{INTRODUCTION}

High-temperature $\left(\sim 120-250^{\circ} \mathrm{C}\right)$ proton exchange membrane fuel cells (HT-PEMFCs), which are increasingly used in promising energy devices, have attracted widespread attention because of their advantages of fast reaction kinetics, high tolerance to fuel/air impurities, and simplified heat and water management [1-3]. The performance of HT-PEMFCs mainly depend on electrocatalysts (the most used one is carbon-supported Pt nanoparticles), but the catalyst degradation is accelerated owing to the enhanced tendency of $\mathrm{Pt}$ oxidation, dissolution, Ostwald ripening, and carbon corrosion at high temperatures [4-6]. The main challenges to improve the HTPEMFC performance and durability are the development of highly durable electrocatalysts and supports that are suitable to run at elevated temperatures with long durability. Carbon sup- ports undergo corrosion leading to delamination of catalyst particles and collapse of the catalyst-layer, further speeding up the dissolution and Ostwald ripening of Pt-based nanoparticles, and resulting in performance degradation or failure of fuel cells [7-11].

In the course of searching electrocatalysts for high-performance electrodes that are suitable for HT-PEMFCs, efforts should be devoted not only to improving both the intrinsic activity and durability of Pt-based nanoparticles, but also to improving the durability of carbon supports. The issues associated with Pt-based catalysts could be resolved to some extent by alloying Pt metals with other metals and by suitable changes in the carbon support [12-17]. Alloying the Pt metal with other metals represents a promising approach to enhance the electrocatalytic performance of Pt-based electrocatalysts, in which the exposure of highly active sites with optimum performance can be maximized [18-26]. Nevertheless, the dealloying of lessnoble elements from $\mathrm{Pt}$ alloys remains an issue for catalyst stability, particularly in HT-PEMFC operating environments $[24,27]$. To overcome these problems, various strategies to stabilize alloy components and structures have been developed, including surface engineering and architectural design [28,29]. Fluorine, with the largest electronegativity, shows doughty bond energy with transition metals [30-32]. Additionally, fluorinated carbon materials show outstanding thermodynamic stability because of the high covalent bond energy of C-F (ca. $480 \mathrm{~kJ} \mathrm{~mol}^{-1}$ ) [33-35]. Thus, using fluorinated carbon as a support and constructing F-containing transition-metal compounds are beneficial to stabilizing the Pt alloy structure and achieving enhanced catalytic performance and durability in an HT-PEMFC operating environment.

Herein, we report dendritic Pt-Ni nanoparticles supported on white carbon black (fluorinated $\mathrm{XC}-72 \mathrm{R}$, the color of the sample changed from black to white, labeled as WCB), which exhibits high oxygen reduction reaction (ORR) activity and increased durability in HT- PEMFCs (Fig. 1a). In the cathode catalyst layer (CCL), a $\mathrm{Ni}_{x} \mathrm{~F}_{y}$ interface on the dendritic Pt-Ni nanoparticles is formed via the interaction between $\mathrm{F}$ and $\mathrm{Ni}$ atoms. The $\mathrm{Ni}_{x} \mathrm{~F}_{y}$ interface inhibits the dealloying process of dendritic $\mathrm{Pt}-\mathrm{Ni}$

\footnotetext{
${ }^{1}$ State Key Laboratory of Chem/Bio-Sensing and Chemometrics, Provincial Hunan Key Laboratory for Graphene Materials and Devices, Advanced Catalytic Engineering Research Center of the Ministry of Education, College of Chemistry and Chemical Engineering, Hunan University, Changsha 410082, China

${ }^{2}$ School of Materials Science and Engineering, Tianjin University, Tianjin 300072, China

${ }^{3}$ College of Materials Science and Engineering, Changsha University of Science \& Technology, Changsha 410083, China

${ }^{4}$ Beijing Key Laboratory of Bioinspired Energy Materials and Devices, School of Space and Environment, Beihang University, Beijing 100191, China

† These authors contributed equally to this work.

* Corresponding authors (emails: taoli@hnu.edu.cn (Tao L); lusf@buaa.edu.cn (Lu S); yi.cheng@csu.edu.cn (Cheng Y); weifeng@tju.edu.cn (Feng W); shuangyinwang@hnu.edu.cn (Wang S))
} 

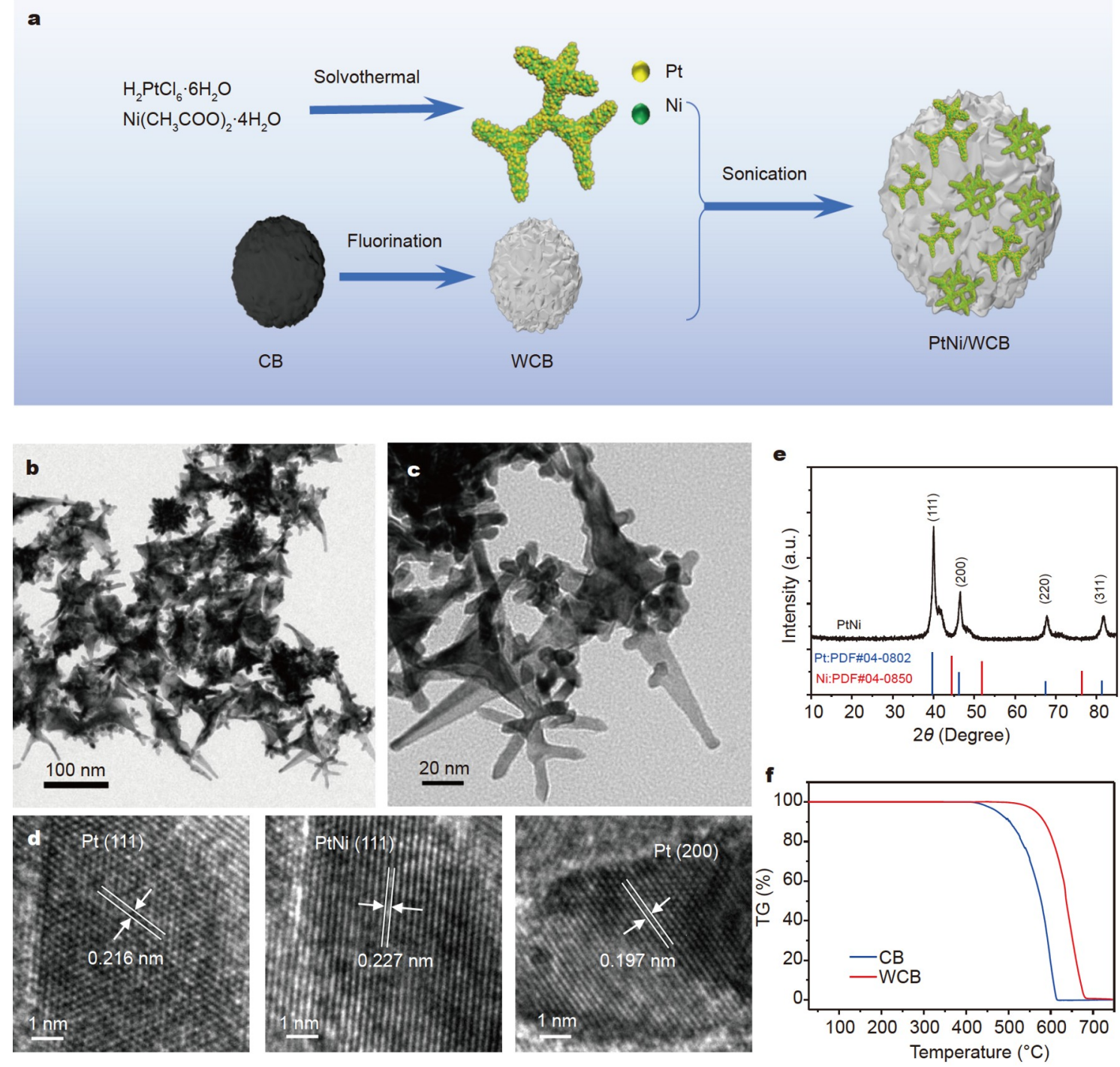

Figure 1 (a) Illustration for the PtNi/WCB fabrication process. (b, c) TEM images of dendritic Pt-Ni nanoparticles. (d) HR-TEM images of dendritic Pt-Ni nanoparticles. (e) XRD patterns of dendritic Pt-Ni nanoparticles. (f) Thermogravimetric analysis (TGA) spectra of CB and WCB.

nanoparticles, and results in the confinement effect of dendritic $\mathrm{Pt}-\mathrm{Ni}$ nanoparticles which is beneficial for restraining the oxidation, dissolution, Ostwald ripening, and agglomeration of Pt. Simultaneously, WCB has better thermal stability, acid resistance, oxidation resistance and corrosion resistance than carbon black (XC-72R), which is also one of the key factors for the stable operation of HT-PEMFCs. Moreover, WCB provides an efficient transport channel for oxygen because of its hydrophobicity. Benefitting from the rational design, the PtNi/WCB catalyst exhibits excellent catalytic activity with durable performance in the rotating disk electrode (RDE) and HT-PEMFC measurements.

\section{EXPERIMENTAL SECTION}

\section{Materials}

Chloroplatinic acid hexahydrate $\left(\mathrm{H}_{2} \mathrm{PtCl}_{6} \cdot 6 \mathrm{H}_{2} \mathrm{O},>99.99 \%\right)$, nickel acetate tetrahydrate $\left(\mathrm{Ni}\left(\mathrm{OCOCH}_{3}\right)_{2} \cdot 4 \mathrm{H}_{2} \mathrm{O}, 99.99 \%\right)$, cetyltrimethylammonium bromide (CTAB, 99\%), and oleyl amine (OAm, 90\%) were all obtained from Sigma-Aldrich (St.
Louis, MO). Carbon black (XC-72R) was obtained from Cabot Corporation. Isopropanol, ethanol, cyclohexane, and $\mathrm{N}, \mathrm{N}$ dimethyl acetamide were purchased commercially (Aladdin, China) and used without further purification. Deionized (DI) water $\left(18.2 \mathrm{M} \Omega \mathrm{cm}^{-1}\right)$ obtained by purification through a Milli$\mathrm{Q}$ system (Millipore, USA) was used throughout the experiments.

\section{Synthesis of dendritic Pt-Ni nanoparticles}

Typically, $\mathrm{H}_{2} \mathrm{PtCl}_{6} \cdot 6 \mathrm{H}_{2} \mathrm{O}, \mathrm{Ni}\left(\mathrm{OCOCH}_{3}\right)_{2} \cdot 4 \mathrm{H}_{2} \mathrm{O}, \mathrm{CTAB}$ and $\mathrm{OAm}$ were added into a vial and ultrasonicated for $1 \mathrm{~h}$ to obtain a homogeneous solution. Subsequently, the mixture was transferred into a Teflon lined autoclave and heated to $180^{\circ} \mathrm{C}$ and maintained for $8 \mathrm{~h}$. The resultant product was then collected by centrifugation and washed five times with an ethanol/cyclohexane mixture (volume ratio of $2 / 1$ ).

\section{Synthesis of WCB}

The CB powder was placed in reactor and the fluorination was performed using $10 \% \mathrm{~F}_{2} / \mathrm{N}_{2}$ gas at temperatures of $300^{\circ} \mathrm{C}$ for at 
least $12 \mathrm{~h}$ to ensure complete reaction. The white fluorinated products were labeled as WCB.

\section{Synthesis of dendritic Pt-Ni nanoparticles/WCB}

The catalysts were prepared by loading the synthesized dendritic Pt-Ni nanoparticles on the WCB, and the loading amount was controlled at $40 \mathrm{wt} \%$. In brief, $40 \mathrm{mg}$ of the obtained products and $60 \mathrm{mg}$ of WCB were mixed in isopropanol under stirring for $12 \mathrm{~h}$, and then the mixture was dried in an oven at $50^{\circ} \mathrm{C}$ overnight. The obtained catalyst was denoted as $\mathrm{PtNi} / \mathrm{WCB}$. For comparison, commercial $\mathrm{Pt} / \mathrm{C}$ (JM $40 \mathrm{wt} \%$ ) was used as the baseline.

\section{RESULTS AND DISCUSSION}

The PtNi/WCB catalyst was synthesized through a two-step method, and Fig. 1a displays the scheme for synthesizing the $\mathrm{PtNi} / \mathrm{WCB}$ catalyst. First, dendritic Pt-Ni nanoparticles were synthesized in $98 \%$ yield from chloroplatinic acid hexahydrate, nickel acetate tetrahydrate, $\mathrm{CTAB}$, and OAm mixtures. They were ultrasonicated and then heated at $180^{\circ} \mathrm{C}$ in a Teflon lined autoclave for $8 \mathrm{~h}$ (Fig. 1a). As shown in the transmission electron microscopy (TEM) images (Fig. 1b, c), disorderly dendritic $\mathrm{Pt}-\mathrm{Ni}$ nanocrystals were formed due to the fast reduction and aggregation of small $\mathrm{Pt}$ and $\mathrm{Ni}$ nuclei at high temperature and confined space [36,37]. The high-resolution TEM (HR-TEM) images (Fig. 1d) reveal lattice fringes of 0.216 and $0.197 \mathrm{~nm}$ corresponding to the (111) and (200) planes of Pt, respectively. Lattice fringes of $0.227 \mathrm{~nm}$ correspond to the (111) Pt-Ni alloy [18]. The X-ray diffraction (XRD) patterns of dendritic Pt-Ni nanoparticles (Fig. 1e) indicate that the dendritic structure consists of $\mathrm{Pt}$ and $\mathrm{PtNi}$ alloy crystal phases, which may be attributed to phase separation caused by different reduction rates between $\mathrm{Pt}$ and $\mathrm{Ni}$ [38]. The inductively coupled plasma mass spectrometry (ICP-MS) result informs 51/49 as the atomic ratio of $\mathrm{Pt} / \mathrm{Ni}$ of dendritic Pt-Ni nanoparticles. The X-ray photoelectron spectroscopy (XPS) survey spectra (Fig. S1) also verify the coexistence of $\mathrm{Pt}$ and $\mathrm{Ni}$ in the as-prepared dendritic $\mathrm{Pt}-\mathrm{Ni}$ nanoparticles, from which the surface atomic ratio of $\mathrm{Pt} / \mathrm{Ni}$ is determined to be 53/47. According to the XPS spectra, the Pt in $\mathrm{Pt} / \mathrm{C}, \mathrm{Pt} / \mathrm{WCB}, \mathrm{PtNi} / \mathrm{CB}, \mathrm{PtNi} / \mathrm{WCB}$ is mainly in the form of metallic $\mathrm{Pt}$ and $\mathrm{Pt}^{2+}$. In many similar literature, platinum exists in both oxidation state and metal state $[39,40]$. The existence of $\mathrm{Pt}^{2+}$ is due to the existence of $\mathrm{Pt}-\mathrm{O}$ bond and $\mathrm{Pt}-\mathrm{Ni}-\mathrm{O}$ bond [41].

Fluorinated carbon black, which was labeled as WCB, was synthesized by direct fluorination using dilute $\mathrm{F}_{2}$ gas (20 vol\%) in $\mathrm{N}_{2}$ gas at $300^{\circ} \mathrm{C}$ to form $\mathrm{CF}_{x}$ compounds. After fluorination treatment, the color of the samples changed from black to white. WCB had better thermal stability than $\mathrm{CB}$ because of the stronger $\mathrm{C}-\mathrm{F}$ bond (Fig. 1f). The XRD (Fig. S2) broadened diffraction peaks of $\mathrm{CB}$ at $24.4^{\circ}$ disappeared, corresponding to the interlayer spacing of the carbon sheets. These results indicated that the graphene hexagonal system was completely fluorinated and maintained the dominant features of amorphous carbon [42-44]. The disordered structures of WCB were confirmed in TEM images (Fig. S3). The XPS spectra of WCB (Fig. S4) suggest the effective fluorination of carbon black. The fluorine and carbon atomic concentrations in the prepared WCB are $52.85 \%$ and $47.15 \%$, respectively, corresponding to a molar ratio of fluorine to carbon (F/C) of 1.12.

The prepared WCB was mixed with dendritic Pt-Ni nano- particles to prepare a $\mathrm{PtNi} / \mathrm{WCB}$ catalyst. Considering both the interfacial mass transfer and electron delivery behavior, $\mathrm{CB}$ was added to the $\mathrm{PtNi} / \mathrm{WCB}$ catalyst to improve the electroconductibility. Thus, the prepared $\mathrm{PtNi} / \mathrm{WCB}$ mixed with $\mathrm{CB}$ (the mass ratio of $\mathrm{WCB} / \mathrm{CB}$ is $1: 1$ ) shows better performance (Fig. S5). For comparison, $\mathrm{Pt} / \mathrm{WCB}, \mathrm{Pt} / \mathrm{CB}$, and $\mathrm{PtNi} / \mathrm{CB}$ were prepared. The $\mathrm{Ni}_{x} \mathrm{~F}_{y}$ signal was observed in high-resolution XPS $\mathrm{Ni} 2 \mathrm{p}$ spectra of PtNi/WCB (Fig. S6a) indicating the formation of a $\mathrm{Ni}_{x} \mathrm{~F}_{y}$ interface during the synthesis of $\mathrm{PtNi} / \mathrm{WCB}$. More importantly, the binding energy of $\mathrm{Pt}$ in $\mathrm{PtNi} / \mathrm{WCB}$ slightly decreases by $0.16 \mathrm{eV}$ compared with bare dendritic $\mathrm{Pt}-\mathrm{Ni}$ nanoparticles (Fig. S6b), indicating a strong interaction between the atomic Pt and the $\mathrm{Ni}_{x} \mathrm{~F}_{y}$ interface [3].

The ORR performances of $\mathrm{PtNi} / \mathrm{WCB}, \mathrm{PtNi} / \mathrm{CB}, \mathrm{Pt} / \mathrm{WCB}, \mathrm{Pt} /$ $\mathrm{CB}$, and commercial $\mathrm{Pt} / \mathrm{C}$ were investigated by cyclic voltammograms (CVs) and linear sweep voltammetry (LSV). The CV of the catalysts was performed in a $\mathrm{N}_{2}$-saturated $\mathrm{HClO}_{4}$ solution $\left(0.1 \mathrm{~mol} \mathrm{~L}^{-1}\right)$ at a sweep rate of $50 \mathrm{mV} \mathrm{s}^{-1}$ at room temperature (Fig. 2a). The electrochemically active surface area (ECSA) was measured by the hydrogen underpotential deposition (HUPD), which was determined by measuring the charge collected in the hydrogen desorption region and assuming a value of $210 \mu \mathrm{Cm}^{-2}$ for a monolayer hydrogen adsorption. The ECSA of $\mathrm{PtNi} / \mathrm{WCB}$ was $71.4 \mathrm{~m}^{2} \mathrm{~g}^{-1} \mathrm{Pt}$, larger than those of $\mathrm{PtNi} / \mathrm{CB}$ $\left(50.5 \mathrm{~m}^{2} \mathrm{~g}^{-1} \mathrm{Pt}\right), \quad \mathrm{Pt} / \mathrm{WCB} \quad\left(60.1 \mathrm{~m}^{2} \mathrm{~g}_{\mathrm{Pt}}^{-1}\right), \quad$ and $\mathrm{Pt} / \mathrm{CB}$ $\left(53.2 \mathrm{~m}^{2} \mathrm{~g}^{-1} \mathrm{Pt}\right.$ ) (Table S1). The enhanced ECSA of PtNi/WCB can be attributed to the formation of $\mathrm{a} \mathrm{Ni}_{x} \mathrm{~F}_{y}$ interface which results in the enhanced dispersion of the $\mathrm{PtNi}$ nanostructure and improves the exposure of a Pt-rich structure. The positive-going ORR LSV curves of the catalysts are further recorded in Fig. $2 \mathrm{~b}$. The half-wave potential of $\mathrm{PtNi} / \mathrm{WCB}$ was $0.934 \mathrm{~V}_{\mathrm{RHE}}$ (RHE: reversible hydrogen electrode), which are $25,16,53$ and $45 \mathrm{mV}$ higher than those of $\mathrm{PtNi} / \mathrm{CB}, \mathrm{Pt} / \mathrm{WCB}, \mathrm{Pt} / \mathrm{CB}$ and commercial $\mathrm{Pt} / \mathrm{C}$, respectively. Except for the commonly accepted enhanced ORR performance through $\mathrm{Pt}-\mathrm{Ni}$ alloying, the better ORR activity of PtNi/WCB and Pt/WCB than $\mathrm{PtNi} / \mathrm{CB}$ and $\mathrm{Pt} / \mathrm{CB}$ was attributed to the hydrophobicity and aerophilicity of WCB, which means much better gas affinity in the $\mathrm{HClO}_{4}$ solution [45-47]. The hydrophobicity of the liquid/gas/solid triphasic interface accelerates the trapping of sufficient oxygen because it affects both the interfacial mass transfer and electron delivery behavior [45,48,49]. Furthermore, the ORR performance of $\mathrm{PtNi} / \mathrm{WCB}$ was enhanced with $\mathrm{Ni}$ leaching, which exposed more active sites after the formation of the $\mathrm{Ni}_{x} \mathrm{~F}_{y}$ interface [18]. The XPS Pt $4 \mathrm{f}$ spectrum of $\mathrm{PtNi} / \mathrm{WCB}$ showed a lower binding energy than other catalysts (Fig. S7), indicating that the formation of the $\mathrm{Ni}_{x} \mathrm{~F}_{y}$ interface would downshift the Pt d-band centre, lowering the binding affinity between $\mathrm{Pt}$ and oxygen intermediates and thus enhancing the ORR activity [41,50].

The durability of the catalysts was evaluated through an accelerated durability test (ADT) between 0.6 and $1.05 \mathrm{~V}_{\mathrm{RHE}}$ in $0.1 \mathrm{~mol} \mathrm{~L}^{-1} \mathrm{HClO}_{4}$ at a scan rate of $100 \mathrm{mV} \mathrm{s}^{-1}$. The $\mathrm{CV}$ and positive LSV curves of the catalysts before and after ADTs are shown in Figs S8-S12. To better understand the durability, the kinetic currents of the catalysts were estimated based on the Koutecky-Levich equation and then normalized against the ECSA and Pt mass to obtain the specific activity (SA) and mass activity (MA) (Fig. 2c, d and Table S1), respectively. The halfwave potential for commercial $\mathrm{Pt} / \mathrm{C}$ has been negatively shifted by $30 \mathrm{mV}$ after 10,000 cycles, and the ORR performances based on SA and MA at $0.9 \mathrm{~V}$ declined by $38.3 \%$ and $38.5 \%$, respec- 

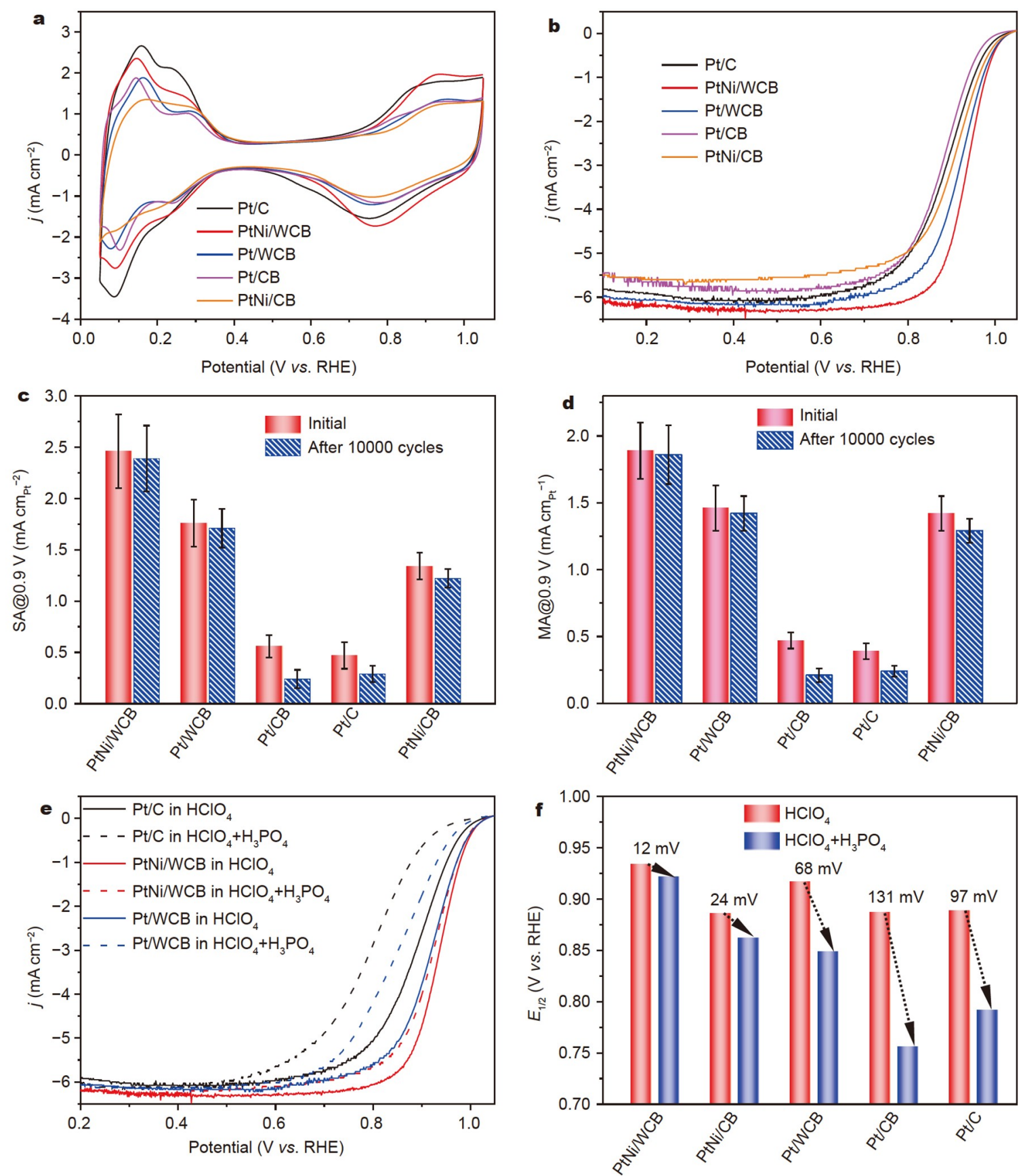

Figure 2 Electrocatalytic ORR performances of commercial $\mathrm{Pt} / \mathrm{C}, \mathrm{PtNi} / \mathrm{WCB}, \mathrm{PtNi} / \mathrm{CB}, \mathrm{Pt} / \mathrm{WCB}$, and $\mathrm{Pt} / \mathrm{CB}$. (a) $\mathrm{CV}$ curves recorded in $\mathrm{N}_{2}$-saturated $\mathrm{HClO} 4$

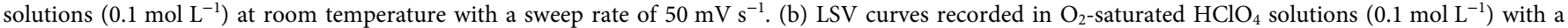

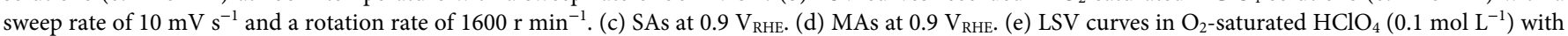
and without the addition of $0.2 \mathrm{~mol} \mathrm{~L}^{-1} \mathrm{H}_{3} \mathrm{PO}_{4}$. (f) Summary of half-wave potential with and without $\mathrm{H}_{3} \mathrm{PO}_{4}$.

tively, which is consistent with the reported references [14]. In contrast, the PtNi/WCB material shows significantly higher durability. The half-wave potential only negatively shifted by $5 \mathrm{mV}$ after the ADT, and the SA and MA only slightly dropped by $0.85 \%$ and $1.59 \%$, respectively. Moreover, PtNi/WCB demonstrated higher durability than $\mathrm{Pt} / \mathrm{CB}$ and commercial $\mathrm{Pt} /$ $\mathrm{C}$, which can be attributed to the strong interaction of PtNi with WCB from a $\mathrm{Ni}_{x} \mathrm{~F}_{y}$ interface to stabilize the PtNi nanostructure. Furthermore, the stable WCB support also contributed to the higher stability. As shown in the Ni 2p XPS spectra (Fig. S13), the peaks of $\mathrm{Ni}_{x} \mathrm{~F}_{y}$ were retained. Furthermore, the $\mathrm{F}$ distribution intersected the entire area of the $\mathrm{Ni}$ and $\mathrm{Pt}$ distribution in the TEM-energy dispersive X-ray spectroscopy (EDS) mapping of the PtNi/WCB catalyst after ADTs of 10,000 cycles (Fig. S14), further indicating that $\mathrm{Ni}_{x} \mathrm{~F}_{y}$ was still distributed on the interface of dendritic Pt-Ni nanoparticles. These results show that the structure of $\mathrm{Ni}_{x} \mathrm{~F}_{y}$ remains stable after $\mathrm{ADT}$, resulting in the high durability of the PtNi/WCB catalyst. HT-PEMFCs run at high temperatures above $120^{\circ} \mathrm{C}$ and depend on $\mathrm{H}_{3} \mathrm{PO}_{4}$ as a dopant to assist the proton conduction in both the proton 
exchange membrane and the catalyst layer [2]. Thus, it is important to investigate the influence of phosphate anions on the ORR performance of Pt-based catalysts. The anti-poisoning properties of the catalysts for $\mathrm{H}_{3} \mathrm{PO}_{4}$ were demonstrated in $\mathrm{O}_{2}$ saturated $\mathrm{HClO}_{4}\left(0.1 \mathrm{~mol} \mathrm{~L}^{-1}\right)$ with and without the addition of $\mathrm{H}_{3} \mathrm{PO}_{4}$ (Fig. 2e). As shown in Fig. 2e, PtNi/WCB exhibited higher resistance to $\mathrm{H}_{3} \mathrm{PO}_{4}$ than $\mathrm{Pt} / \mathrm{WCB}$ and commercial $\mathrm{Pt} / \mathrm{C}$. The half-wave potential of $\mathrm{PtNi} / \mathrm{WCB}$ only negatively shifted by $12 \mathrm{mV}$ after the addition of $\mathrm{H}_{3} \mathrm{PO}_{4}$, which is significantly lower than that of $24,68,131$, and $97 \mathrm{mV}$ for $\mathrm{PtNi} / \mathrm{CB}, \mathrm{Pt} / \mathrm{WCB}, \mathrm{Pt} / \mathrm{CB}$ and $\mathrm{Pt} / \mathrm{C}$, respectively (Fig. 2f). $\mathrm{PtNi} / \mathrm{WCB}$ and $\mathrm{PtNi} / \mathrm{CB}$ exhibited better resistance to $\mathrm{H}_{3} \mathrm{PO}_{4}$ than $\mathrm{Pt} / \mathrm{WCB}$ and $\mathrm{Pt} / \mathrm{CB}$. The results reflected that the anti-poisoning property of $\mathrm{H}_{3} \mathrm{PO}_{4}$ was mainly attributed to the alloy effect of PtNi and partially due to the hydrophobic property of WCB, which relieves the adsorption of phosphate anions.

The performance of HT-PEMFCs using the catalysts as the cathode catalyst was evaluated at $160^{\circ} \mathrm{C}$ under anhydrous $\mathrm{H}_{2} / \mathrm{O}_{2}$ at atmospheric pressure using commercial $\mathrm{Pt} / \mathrm{C}$ as the anode. The design of HT-PEMFC fixture is shown in Fig. 3a. $\mathrm{A} \mathrm{H}_{3} \mathrm{PO}_{4}-$ doped poly(ethersulfone)-poly(vinyl pyrrolidone) (PES-PVP) membrane was used as the electrolyte $[51,52]$. In our previous study, the synthesis method and specific parameters of the membrane have been reported [53]. The sandwich-like structure of PtNi/WCB MEA (MEA: membrane electrode assembly) prepared by catalyst-coated substrates (CCS) is shown in Fig. 3b [54,55]. Fig. 3c, d compare the HT-PEMFC performance of the MEAs. The PtNi/WCB MEA exhibited a superior performance compared with that of other MEAs (including PtNi/CB, Pt/ WCB, Pt/CB, and commercial Pt/C MEAs), consistent with previous ORR performance. The peak power density of the $\mathrm{PtNi}$ / WCB MEA is $906 \mathrm{~mW} \mathrm{~cm}^{-2}$, which is approximately 1.26 and 1.36 times that of the PtNi/CB MEA and Pt/C MEA with 718 and $666 \mathrm{~mW} \mathrm{~cm}^{-2}$, respectively.

The durability test of the MEAs was performed under a constant cell current density of $0.2 \mathrm{~A} \mathrm{~cm}^{-2}$ at $160^{\circ} \mathrm{C}$ (Fig. S15). The PtNi/WCB shows a voltage of $0.763 \mathrm{~V}$ to achieve a current density $0.2 \mathrm{~A} \mathrm{~cm}^{-2}$ after $25 \mathrm{~h}$, which is higher than that of 0.717 , $0.731,0.707$, and $0.654 \mathrm{~V}$ for $\mathrm{PtNi} / \mathrm{CB}, \mathrm{Pt} / \mathrm{WCB}$, commercial Pt/ $\mathrm{C}$ and $\mathrm{Pt} / \mathrm{CB}$ MEAs, respectively, which is consistent with the LSV results in Fig. 2b. It is worth noting that the PtNi/WCB MEA exhibited stable performance under different current densities from 0.2 to $2.0 \mathrm{~A} \mathrm{~cm}^{-2}$ (Fig. S16). These results clearly demonstrate the superior durability of the fuel cell using PtNi/ WCB as the cathode catalyst.

To better understand the durability mechanism of PtNi/WCB, a long-term durability test of PtNi/WCB MEA under $0.2 \mathrm{~A} \mathrm{~cm}^{-2}$ was evaluated at $160^{\circ} \mathrm{C}$ for $200 \mathrm{~h}$ (Fig. $4 \mathrm{a}$ ). The cell voltage to achieve a current density of $0.2 \mathrm{~A} \mathrm{~cm}^{-2}$ remains at $\sim 0.75 \mathrm{~V}$ after $200 \mathrm{~h}$ of testing, indicating the high durability of the PtNi/WCB MEA. After the long-term durability test, the peak power density of the $\mathrm{PtNi} / \mathrm{WCB}$ MEA only slightly decreased by $3.2 \%$ $\left(29 \mathrm{~mW} \mathrm{~cm}^{-2}\right.$ ) (Fig. S17). In addition, the charge transport resistance of the PtNi/WCB MEA was quantified by electrochemical impedance spectroscopy (EIS) (Fig. S18). As shown in Fig. S18, the charge transport resistance $\left(R_{\mathrm{ct}}\right)$ of $\mathrm{PtNi} / \mathrm{WCB}$ is
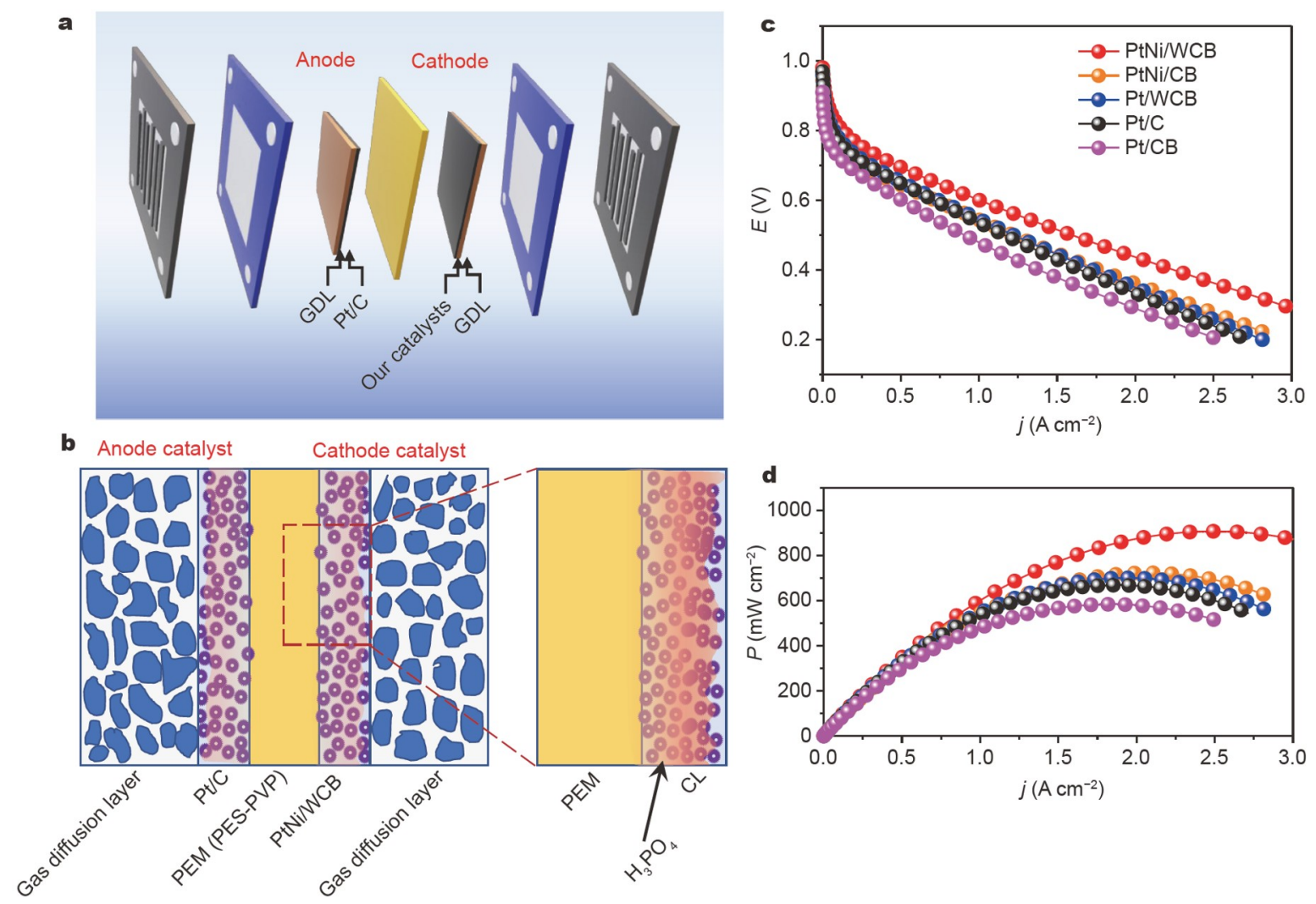

Figure $3 \quad \mathrm{H}_{2} / \mathrm{O}_{2}$ HT-PEMFC performances of commercial Pt/C, PtNi/WCB, PtNi/CB, Pt/WCB, and Pt/CB as cathode catalysts. (a) Schematic diagram of HT-PEMFCs fixture. GDL stands for gas diffusion layer. (b) The structure of membrane electrode assembly. (c) Polarization curves. (d) Specific power density curves. Testing conditions: $1.0 \mathrm{mg} \mathrm{cm}{ }^{-2}$ commercial Pt/C in the anode, $>1.0 \mathrm{mg} \mathrm{cm}^{-2}$ catalysts in the cathode; all the fuel cell performance was measured at $\mathrm{H}_{2} / \mathrm{O}_{2}\left(200 / 200 \mathrm{~mL} \mathrm{~min}^{-1}\right)$ under $101.3 \mathrm{kPa}$ without humidification at $160^{\circ} \mathrm{C}$. 

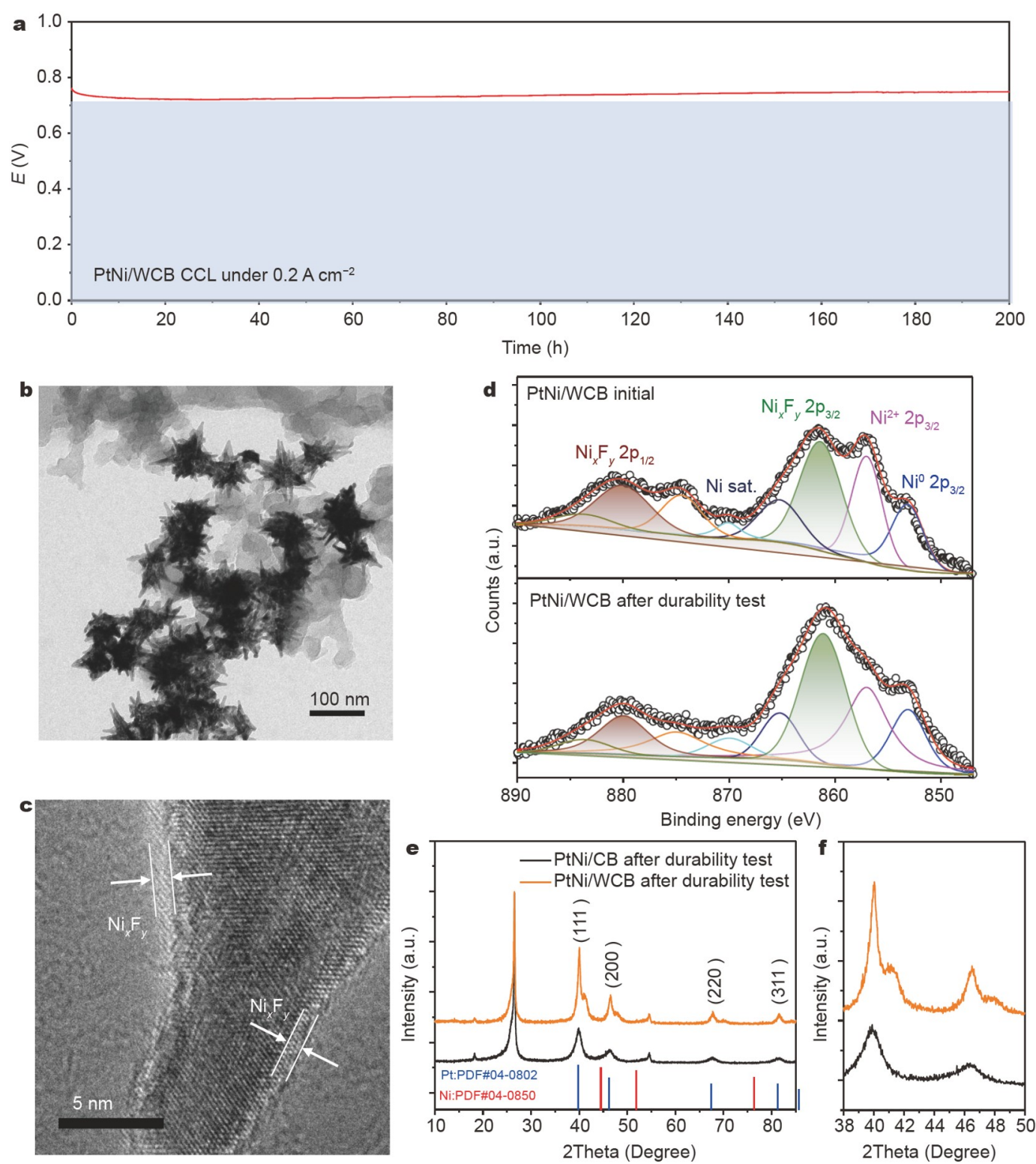

Figure 4 Durability and structural fluctuation of PtNi/WCB MEA. (a) Durability test under $0.2 \mathrm{~A} \mathrm{~cm}^{-2}$; (b) TEM and (c) HR-TEM images of the PtNi/WCB cathode catalyst after long-term durability test of $200 \mathrm{~h}$. (d) Ni 2p XPS spectra of PtNi/WCB before and after long-term durability test of $200 \mathrm{~h}$. (e, f) XRD patterns of $\mathrm{PtNi} / \mathrm{WCB}$ and $\mathrm{PtNi} / \mathrm{CB}$ after durability test.

fitted as $89.6 \mathrm{~m} \Omega \mathrm{cm}^{2}$ and manifests only a slight increase of $0.5 \mathrm{~m} \Omega \mathrm{cm}^{2}$ after durability test for $200 \mathrm{~h}$.

The TEM micrographs of the PtNi/WCB catalyst after the long-term durability test indicated no sign of change in the structural morphology of the dendritic architecture (Fig. 4b), further supporting the stable structure of the PtNi/WCB catalyst layer. In addition, an obvious coating at the interface of the dendritic Pt-Ni nanoparticles can be observed, which is assigned to the $\mathrm{Ni}_{x} \mathrm{~F}_{y}$ interface (Fig. 4c). As shown in TEM-EDS mapping of the PtNi/WCB cathode catalyst after a durability test of $200 \mathrm{~h}$. (Fig. S19), the distribution of $\mathrm{F}$ intersects the entire region of $\mathrm{Ni}$ and $\mathrm{Pt}$, while the $\mathrm{C}$ signal is inconspicuous in the intersecting region, indicating that $\mathrm{F}$ atoms are adsorbed on dendritic $\mathrm{Pt}-\mathrm{Ni}$ nanoparticles. To better understand the origin of the high durability of the PtNi/WCB, the structures of the PtNi/WCB MEA before and after the long-term durability test were investigated.
As shown in cross-sectional SEM images of PtNi/WCB CCL (Fig. S20), the distribution and morphology of Pt-Ni nanoparticles were not changed after the long-term durability test. The Ni $2 p$ and Pt 4 f XPS spectra of the PtNi/WCB CCL before and after the long-term durability test were compared (Fig. $4 \mathrm{~d}$ and Fig. S21). As shown in the Ni 2p XPS spectrum (Fig. 4d), the deconvolution of the $\mathrm{Ni}$ peak shows that the intensity for $\mathrm{Ni}_{x} \mathrm{~F}_{y}$ rises after the long-term durability test due to the in-situ growth of $\mathrm{Ni}_{x} \mathrm{~F}_{y}$ under electrochemical conditions. Simultaneously, the Pt $4 \mathrm{f}$ peaks of the PtNi/WCB (Fig. S21b) shift to higher binding energies because of the further formation of $\mathrm{Ni}_{x} \mathrm{~F}_{y}$ interface, resulting in more exposure to platinum atoms. To further confirm the superiority of $\mathrm{Ni}_{x} \mathrm{~F}_{y}$, we compared the physical phases of the PtNi/WCB and PtNi/CB catalysts by XRD (Fig. 4e, f). The PtNi alloy crystal phase was still observed in the XRD pattern of $\mathrm{PtNi} / \mathrm{WCB}$ after the durability test, whereas the alloy signal 
disappeared in $\mathrm{PtNi} / \mathrm{CB}$, indicating severe dealloying without the $\mathrm{Ni}_{x} \mathrm{~F}_{y}$ interface. The XPS spectra of $\mathrm{PtNi} / \mathrm{CB}$ further indicated the dealloying of $\mathrm{Ni}$ atoms (Fig. S22). After the durability test for $200 \mathrm{~h}$, the surface atomic ratio of $\mathrm{Ni}$ was decreased to $0.17 \mathrm{at} \%$ compared with 2.07 at\% before the durability test (Table S2). However, the surface atomic ratio of $\mathrm{Pt} / \mathrm{Ni}$ of $\mathrm{PtNi} / \mathrm{WCB}$ only exhibited slight volatility after durability test for $200 \mathrm{~h}$. In contrast, the commercial $\mathrm{Pt} / \mathrm{C}$ in the cathode catalyst demonstrated poor stability and the size of Pt nanoparticles exhibited a significant increase after the durability test (Fig. S23).

\section{CONCLUSIONS}

In summary, high-performance $\mathrm{PtNi} / \mathrm{WCB}$ catalysts were constructed with high performance and better durability in HTPEMFCs by loading dendritic Pt-Ni nanoparticles onto fluorinated carbon black. The PtNi/WCB MEA in the HT-PEMFCs reached a peak power density of $906 \mathrm{~mW} \mathrm{~cm}^{-2}$ at $160^{\circ} \mathrm{C}$ under $\mathrm{H}_{2} / \mathrm{O}_{2}$ conditions and only slightly decreased by $29 \mathrm{~mW} \mathrm{~cm}$ after the $200 \mathrm{~h}$ long-term durability tests, substantially outperforming commercial Pt/C MEA. A nanoscale $\mathrm{Ni}_{x} \mathrm{~F}_{y}$ interface were observed and demonstrated, which results in the high durability due to strong catalyst-support interactions and suppressed dealloying under electrochemical conditions. This study offers a robust and potential methodology for improving the activity and durability of HT-PEMFCs.

\section{Received 11 August 2021; accepted 21 October 2021; published online 22 November 2021}

1 Atanasov V, Lee AS, Park EJ, et al. Synergistically integrated phosphonated poly(pentafluorostyrene) for fuel cells. Nat Mater, 2021, 20: 370-377

2 Haider R, Wen $\mathrm{Y}, \mathrm{Ma} \mathrm{ZF}$, et al. High temperature proton exchange membrane fuel cells: Progress in advanced materials and key technologies. Chem Soc Rev, 2021, 50: 1138-1187

3 Lim SY, Martin S, Gao G, et al. Self-standing nanofiber electrodes with Pt-Co derived from electrospun zeolitic imidazolate framework for high temperature PEM fuel cells. Adv Funct Mater, 2021, 31: 2006771

4 Sui S, Wang X, Zhou X, et al. A comprehensive review of Pt electrocatalysts for the oxygen reduction reaction: Nanostructure, activity, mechanism and carbon support in PEM fuel cells. J Mater Chem A, 2017, 5: 1808-1825

5 Gao Y, Hou M, He L, et al. Performance- and durability-enhanced carbon-skeleton nanofiber electrode with $\mathrm{Pt}_{3} \mathrm{Co} / \mathrm{C}$ for PEMFCs. ACS Sustain Chem Eng, 2020, 8: 13030-13038

6 Wang G, Yang Z, Du Y, et al. Programmable exposure of Pt active facets for efficient oxygen reduction. Angew Chem Int Ed, 2019, 58: 15848-15854

7 Kondratenko MS, Gallyamov MO, Tyutyunnik OA, et al. Degradation of high temperature polymer electrolyte fuel cell cathode material as affected by polybenzimidazole. J Electrochem Soc, 2015, 162: F587F595

8 Ignaszak A, Song $\mathrm{C}$, $\mathrm{Zhu} \mathrm{W}$, et al. Carbon- $\mathrm{Nb}_{0.07} \mathrm{Ti}_{0.93} \mathrm{O}_{2}$ composite supported Pt-Pd electrocatalysts for PEM fuel cell oxygen reduction reaction. Electrochim Acta, 2012, 75: 220-228

9 Xie Z, Cheng H, Chen Z, et al. A general strategy for synthesizing hierarchical architectures assembled by dendritic Pt-based nanoalloys for electrochemical hydrogen evolution. Int J Hydrogen Energy, 2021, 46: 11573-11586

10 Wang D, Chen Z, Huang YC, et al. Tailoring lattice strain in ultra-fine high-entropy alloys for active and stable methanol oxidation. Sci China Mater, 2021, 64: 2454-2466

11 Meyers JP, Darling RM. Model of carbon corrosion in PEM fuel cells. J Electrochem Soc, 2006, 153: A1432

12 You DJ, Kim DH, De Lile JR, et al. Pd core-shell alloy catalysts for high- temperature polymer electrolyte membrane fuel cells: Effect of the core composition on the activity towards oxygen reduction reactions. Appl Catal A-Gen, 2018, 562: 250-257

13 Yao D, Zhang W, Ma Q, et al. Achieving high Pt utilization and superior performance of high temperature polymer electrolyte membrane fuel cell by employing low-Pt-content catalyst and microporous layer free electrode design. J Power Sources, 2019, 426: 124-133

14 Devrim Y, Arıca ED. Multi-walled carbon nanotubes decorated by platinum catalyst for high temperature PEM fuel cell. Int J Hydrogen Energy, 2019, 44: 18951-18966

15 Lobato J, Zamora H, Plaza J, et al. Enhancement of high temperature PEMFC stability using catalysts based on Pt supported on SiC based materials. Appl Catal B-Environ, 2016, 198: 516-524

16 Yang F, Ye JY, Yuan Q, et al. Ultrasmall Pd-Cu-Pt trimetallic twin icosahedrons boost the electrocatalytic performance of glycerol oxidation at the operating temperature of fuel cells. Adv Funct Mater, 2020, 30: 1908235

17 Yang X, Yao K, Ye JY, et al. Interface-rich three-dimensional Au-doped PtBi intermetallics as highly effective anode catalysts for application in alkaline ethylene glycol fuel cells. Adv Funct Mater, 2021, 31: 2103671

18 Tian X, Zhao X, Su YQ, et al. Engineering bunched Pt-Ni alloy nanocages for efficient oxygen reduction in practical fuel cells. Science, 2019, 366: $850-856$

19 Wang Q, Chen F, Guo L, et al. Nanoalloying effects on the catalytic activity of the formate oxidation reaction over $\mathrm{AgPd}$ and $\mathrm{AgCuPd}$ aerogels. J Mater Chem A, 2019, 7: 16122-16135

20 Wang J, Chen F, Jin Y, et al. In situ high-potential-driven surface restructuring of ternary AgPd-Pt dilute aerogels with record-high performance improvement for formate oxidation electrocatalysis. Nanoscale, 2019, 11: 14174-14185

21 Tang Q, Chen F, Jin T, et al. Alloying in inverse $\mathrm{CeO}_{2} / \mathrm{Pd}$ nanoparticles to enhance the electrocatalytic activity for the formate oxidation reaction. J Mater Chem A, 2019, 7: 22996-23007

22 Guo L, Chen F, Jin T, et al. Surface reconstruction of AgPd nanoalloy particles during the electrocatalytic formate oxidation reaction. Nanoscale, 2020, 12: 3469-3481

23 Pan B, Chen F, Kou B, et al. Unexpectedly high stability and surface reconstruction of PdAuAg nanoparticles for formate oxidation electrocatalysis. Nanoscale, 2020, 12: 11659-11671

24 Debe MK. Electrocatalyst approaches and challenges for automotive fuel cells. Nature, 2012, 486: 43-51

25 Chattot R, Le Bacq O, Beermann V, et al. Surface distortion as a unifying concept and descriptor in oxygen reduction reaction electrocatalysis. Nat Mater, 2018, 17: 827-833

26 van der Vliet DF, Wang C, Tripkovic D, et al. Mesostructured thin films as electrocatalysts with tunable composition and surface morphology. Nat Mater, 2012, 11: 1051-1058

27 Bing Y, Liu H, Zhang L, et al. Nanostructured Pt-alloy electrocatalysts for PEM fuel cell oxygen reduction reaction. Chem Soc Rev, 2010, 39: 2184-2202

28 Kwon H, Kabiraz MK, Park J, et al. Dendrite-embedded platinumnickel multiframes as highly active and durable electrocatalyst toward the oxygen reduction reaction. Nano Lett, 2018, 18: 2930-2936

29 Vedarajan R, Prithi J, Rajalakshmi N. Advanced nano-catalysts for fuelcell technologies. In: Naushad M, Saravanan R, Kumar R (EDs.). Nanomaterials for Sustainable Energy and Environmental Remediation. Amsterdam: Elsevier, 2020. 165-191.

30 Long P, Feng Y, Cao C, et al. Self-protective room-temperature phosphorescence of fluorine and nitrogen codoped carbon dots. Adv Funct Mater, 2018, 28: 1800791

31 Feng W, Long P, Feng Y, et al. Two-dimensional fluorinated graphene: Synthesis, structures, properties and applications. Adv Sci, 2016, 3: 1500413

32 Yang Y, Ruan G, Xiang C, et al. Flexible three-dimensional nanoporous metal-based energy devices. J Am Chem Soc, 2014, 136: 6187-6190

33 Lee YS. Syntheses and properties of fluorinated carbon materials. J Fluorine Chem, 2007, 128: 392-403

34 Liang C, Li Z, Dai S. Mesoporous carbon materials: Synthesis and modification. Angew Chem Int Ed, 2008, 47: 3696-3717 
35 Enyashin AN, Ivanovskii AL. Fluorinated derivatives of $\mathrm{sp}^{2}$ graphene allotropes: Structure, stability, and electronic properties. Chem Phys Lett, 2012, 545: 78-82

36 Lim B, Xia Y. Metal nanocrystals with highly branched morphologies. Angew Chem Int Ed, 2011, 50: 76-85

37 Wang F, Li C, Sun LD, et al. Porous single-crystalline palladium nanoparticles with high catalytic activities. Angew Chem Int Ed, 2012, 51: $4872-4876$

38 Nassr ABAA, Sinev I, Grünert W, et al. PtNi supported on oxygen functionalized carbon nanotubes: In depth structural characterization and activity for methanol electrooxidation. Appl Catal B-Environ, 2013, 142-143: 849-860

39 Ahmadi M, Behafarid F, Cui C, et al. Long-range segregation phenomena in shape-selected bimetallic nanoparticles: Chemical state effects. ACS Nano, 2013, 7: 9195-9204

40 Zou L, Fan J, Zhou Y, et al. Conversion of PtNi alloy from disordered to ordered for enhanced activity and durability in methanol-tolerant oxygen reduction reactions. Nano Res, 2015, 8: 2777-2788

41 Zhao Z, Liu H, Gao W, et al. Surface-engineered PtNi-O nanostructure with record-high performance for electrocatalytic hydrogen evolution reaction. J Am Chem Soc, 2018, 140: 9046-9050

42 Zhou J, Lian J, Hou L, et al. Ultrahigh volumetric capacitance and cyclic stability of fluorine and nitrogen co-doped carbon microspheres. Nat Commun, 2015, 6: 8503

43 Peng C, Li Y, Yao F, et al. Ultrahigh-energy-density fluorinated calcinated macadamia nut shell cathodes for lithium/fluorinated carbon batteries. Curr Alzheimer Resbon, 2019, 153: 783-791

44 Sansotera M, Navarrini W, Resnati G, et al. Preparation and characterization of superhydrophobic conductive fluorinated carbon blacks. Curr Alzheimer Resbon, 2010, 48: 4382-4390

45 Wang $\mathrm{P}$, Hayashi T, Meng Q, et al. Highly boosted oxygen reduction reaction activity by tuning the underwater wetting state of the superhydrophobic electrode. Small, 2017, 13: 1601250

46 Li Y, Zhang $\mathrm{H}$, Han N, et al. Janus electrode with simultaneous management on gas and liquid transport for boosting oxygen reduction reaction. Nano Res, 2019, 12: 177-182

47 Chen Y, Cai J, Li P, et al. Hexagonal boron nitride as a multifunctional support for engineering efficient electrocatalysts toward the oxygen reduction reaction. Nano Lett, 2020, 20: 6807-6814

48 Chidsey CED. Free energy and temperature dependence of electron transfer at the metal-electrolyte interface. Science, 1991, 251: 919-922

49 Lei Y, Sun R, Zhang X, et al. Oxygen-rich enzyme biosensor based on superhydrophobic electrode. Adv Mater, 2016, 28: 1477-1481

50 Li Z, Niu W, Yang Z, et al. Stabilizing atomic Pt with trapped interstitial $\mathrm{F}$ in alloyed PtCo nanosheets for high-performance zinc-air batteries. Energy Environ Sci, 2020, 13: 884-895

51 Ho VTT, Pan CJ, Rick J, et al. Nanostructured $\mathrm{Ti}_{0.7} \mathrm{Mo}_{0.3} \mathrm{O}_{2}$ support enhances electron transfer to Pt: High-performance catalyst for oxygen reduction reaction. J Am Chem Soc, 2011, 133: 11716-11724

52 Zhang S, Zhang J, Zhu Z, et al. Unusual influence of binder composition and phosphoric acid leaching on oxygen mass transport in catalyst layers of high-temperature proton exchange membrane fuel cells. J Power Sources, 2020, 473: 228616

53 Xu X, Wang $\mathrm{H}, \mathrm{Lu} \mathrm{S}$, et al. A novel phosphoric acid doped poly (ethersulphone)-poly(vinyl pyrrolidone) blend membrane for hightemperature proton exchange membrane fuel cells. J Power Sources, 2015, 286: 458-463

54 Bai $\mathrm{H}$, Wang $\mathrm{H}$, Zhang J, et al. Simultaneously enhancing ionic conduction and mechanical strength of poly(ether sulfones)-poly(vinyl pyrrolidone) membrane by introducing graphitic carbon nitride nanosheets for high temperature proton exchange membrane fuel cell application. J Membrane Sci, 2018, 558: 26-33

55 Huah L, Majlan E, Tajuddin A, et al. Comparison of catalyst-coated membranes and catalyst-coated substrate for PEMFC membrane electrode assembly: A review. Chinese J Chem Eng, 2021, 33: 1-16

Acknowledgements This work was supported by the National Key R\&D Program of China (2020YFA0710000), the National Natural Science Foun- dation of China (21825201 and U19A2017), the Provincial Natural Science Foundation of Hunan (2019GK2031, 2016TP1009 and 2020JJ5045), China Postdoctoral Science Foundation (2020M682541), the Science and Technology Innovation Program of Hunan Province, China (2020RC2020), and Changsha Municipal Natural Science Foundation (kq2007009).

Author contributions Long $\mathrm{P}, \mathrm{Du}$ S, and Liu Q conceived the idea and wrote the paper; Long P, Gu K and Liu Q performed the synthesis and basic characterization of the samples. Du S, Wang T, Xie C and Peng C conducted the fuel cell test. Tao L, Zhang Y, Chen R, Lu S, Cheng Y, Feng W and Wang $S$ discussed the mechanism of action and directed the writing of the paper. All the authors contributed to the overall scientific interpretation and edited the manuscript.

Conflict of interest The authors declare that they have no conflict of interest.

Supplementary information Experimental details and supporting data are available in the online version of the paper.

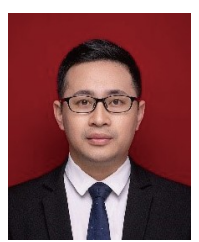

Peng Long received his Master degree in 2014 from $\mathrm{Hu}$ nan University of Science and Technology and his $\mathrm{PhD}$ degree in 2018 from Tianjin University under the supervision of Prof. Wei Feng. He currently works at Hunan University as a postdoctoral researcher under the supervision of Prof. Shuangyin Wang. His research interests include the synthesis and characterization of nanomaterials as electrocatalysts for proton exchange membrane fuel cells.

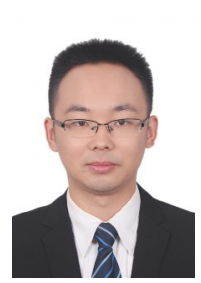

Shiqian Du received his Master degree in 2016 from Beijing University of Chemical Technology, China. He is pursuing his $\mathrm{PhD}$ degree under the supervision of Prof. Shuangyin Wang at Hunan University. His research in terests are electrochemical catalysis and related devices.

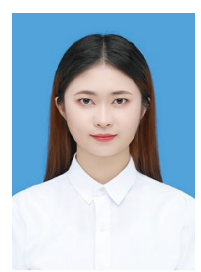

Qie Liu received her Bachelor's degree in 2020 from Hunan University. She is pursuing her $\mathrm{PhD}$ degree under the supervision of Prof. Shuangyin Wang at Hunan University. Her research interest includes the design of electrocatalysts and their applications in high-temperature proton exchange membrane fuel cells.

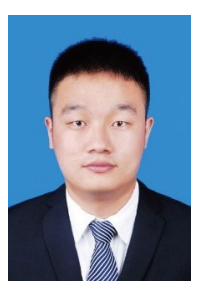

Li Tao received his Master degree in 2016 and his $\mathrm{PhD}$ degree in 2019 from Hunan University under the supervision of Prof. Shuangyin Wang. He is currently an assistant professor at the Provincial Hunan Key Laboratory for Graphene Materials, College of Chemistry and Chemical Engineering, Hunan University. His research interests are in plasma technology, defect chemistry and fuel cells. 


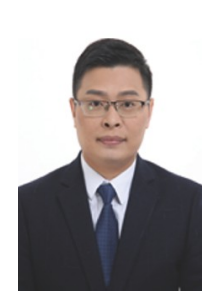

Shuangyin Wang received his BSc degree in 2006 from Zhejiang University and his $\mathrm{PhD}$ degree in 2010 from Nanyang Technological University, Singapore. He is currently a professor of the Key Provincial Hunan Key Laboratory for Graphene Materials, College of Chemistry and Chemical Engineering, Hunan University. His research interests are in plasma technology, defects in various crystals and their application for electrochemical energy storage and conversion.

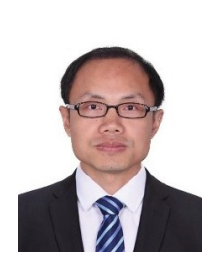

Shanfu Lu received his $\mathrm{PhD}$ in physical chemistry from Wuhan University in 2008, and then joined Nanyang Technological University in Singapore as a postdoctoral researcher. He joined the Department of Environmental Science and Engineering of Beihang University as a professor in 2009. He is mainly engaged in the research of key materials and devices for polymer electrolyte membrane fuel cells and liquid flow batteries.

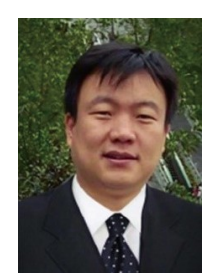

Wei Feng received his $\mathrm{PhD}$ degree in 2000 from Xi'an Jiaotong University of China after studying the opticalelectrical properties and device applications of novel conducting polymers, and then worked at Osaka University and Tsinghua University as a Japan Science Promotion Society (JSPS) fellow and postdoctoral researcher, respectively. In 2004, he became a full professor at Tianjin University, where he has been working on functional nanocarbon materials.

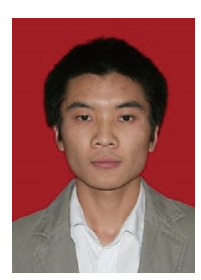

Yi Cheng received his Master degree in environmental engineering from Central South University in 2006 and his $\mathrm{PhD}$ degree in 2014 from Curtin University. His research interests are environmental functional materials, clean energy materials and devices, electrochemical catalysts for pollutant degradation and mechanisms.

\section{氟化物界面抑制PtNi电催化剂去合金化及其高温质 子交换膜燃料电池性能研究}

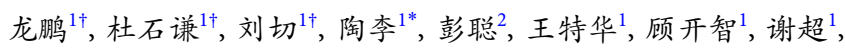
张怡琼 ${ }^{3}$, 陈如 ${ }^{1}$, 卢善富 ${ }^{*}$, 程义 ${ }^{1 *}$, 封伟 $2^{*}$, 王双印 $1^{*}$

摘要 高温质子交换膜燃料电池(HT-PEMFCs) 以其杂质耐受性高、系 统简化等突出优势为燃料电池的发展带来了新机遇. 目前广泛使用的 铂碳催化剂存在严重的颗粒团聚、载体腐蚀等耐久性较差问题. 本文 采用氟化碳黑(白碳黑)负载的枝状Pt-Ni纳米颗粒作为HT-PEMFCs阴 极催化剂, 由于 $\mathrm{Ni} 、 \mathrm{~F}$ 强相互作用并在Pt-Ni合金表面形成了 $\mathrm{Ni}_{x} \mathrm{~F}_{y}$ 界面, 可显著提升器件性能和耐受性, 在 $160^{\circ} \mathrm{C} 、 干$ 燥 $\mathrm{H}_{2} / \mathrm{O}_{2}$ 条件下峰功率密 度可达 $906 \mathrm{~mW} \mathrm{~cm}^{-2}$. 本文成功利用 $\mathrm{Ni}_{x} \mathrm{~F}_{y}$ 界面提升合金催化剂的活性 和稳定性, 对于HT-PEMFCs催化剂的设计具有指导意义. 